Enzo Solari

Escuela de Derecho

Universidad Católica del Norte

\title{
Heideggerius gnosticus? \\ El sentido del recurso heideggeriano a la divinidad $(*)$
}

Para Martin Heidegger, la cuestión de Dios fue efectivamente una cuestión. En los orígenes de su propia trayectoria vital tuvo importancia el cristianismo en su versión católica. Y aunque renegara relativamente pronto del sistema católico, no parece haber abandonado nunca del todo la fe cristiana. Por otra parte, es sabido que no fueron pacíficas sus relaciones intelectuales con la teología, particularmente con la enormidad de su influjo metafísico. En su obra se aprecia una enérgica batalla con las consecuencias filosóficas del cristianismo. Sin embargo, su valoración del mismo es ambigua: si por un lado denuncia la impureza meditativa de la onto-teología de la tradición occidental (que en todo caso remonta -más allá del evento cristianohasta la misma filosofía griega, sobre todo la de Platón y Aristóteles, y que incluso enlaza -ya desde Homero- con el predominio del juicio y de la verdad predicativa sobre el lucimiento rigurosamente antepredicativo de la alétheia), por el otro destaca las virtualidades del cristianismo originario anterior a la esclerotización eclesiástica y mundanal (en especial por su radical concepción de la gracia divina, del escándalo salvífico de la cruz, del acto abismático de la fe y de la temporalidad de la existencia humana).

Puede decirse todavía más. Independientemente de estas sus relaciones con el cristianismo, Heidegger mantuvo un comercio constante con lo divino. Es cierto que en el período de Ser y tiempo llevó a cabo una ontología fundamental conducida a través de una analítica de la existencia marcadamente agnóstica (atea en sus propias palabras), por pretender que tal era el procedimiento formalmente filosófico. Mas, también es cierto que dicho ateísmo era puramente procedimental, no decidiendo nada en absoluto acerca de la posibilidad de una relación humana con Dios. Además, tanto antes como después de aquella época Heidegger se empleó a fondo en la exploración de unos problemas en los cuales la noción de Dios resultaba insoslayable. No es exagerado afirmar por eso que Heidegger trató de elaborar, si bien de manera intensamente peculiar, una idea de Dios. Esto es algo que emerge muy acusadamente en esa filosofía que diseñó una y otra vez a partir de su giro (Kehre)

(*) El autor agradece los comentarios que hizo a este texto Antonio González, quien de todos modos no es responsable de las tesis aquí sostenidas. 
de los años 30. Es entonces cuando levanta la expresión 'último Dios' (letzter Gott) sobre el trasfondo misterioso y sagrado de la verdad del ser (Wahrheit des Seyns) que se va desplegando en la cuaterna (Geviert) de tierra y cielo, mortales y divinos. En efecto, el claro (Lichtung) del cual todo brota (physei), ese acontecimiento apropiante (Ereignis) del que penden el ser, el tiempo y el mismo hombre, remite inamisiblemente a aquella sacralidad salvífica que han cantado los poetas, vislumbrado los místicos y preguntado los pensadores (en cierta forma, los auténticos creyentes). Y es que la única salvación posible, piensa Heidegger, obedece a una divinidad que está históricamente de paso o en tránsito (im Vorbeigang, dice), que no se hace notar de otro modo que por señas (Winke), y que en todo caso es distinta de la que testimonian las religiones. De ahí que subraye, al mismo tiempo, que la acogida de ese fugaz tránsito divino supone la constitución de una nueva manera de habitar el mundo, de un dejamiento sereno y moroso (Gelassenheit), que protege pastoralmente el clarísimo acontecimiento del ser y es respetuoso de la tierra y las cosas, de la vida y la existencia. He ahí, según Heidegger, la única esperanza humana en sobrevivir a las amenazas expoliadoras de la moderna civilización técnica y atómica.

¿Qué decir de este recurso a la divinidad? Al menos, que ha sido apreciado muy disparmente. Algunos advierten en él una genial visión de Dios y unas intuiciones sumamente seminales para la teología cristiana. Otros denuncian aquí uno de los resortes más débiles de la filosofía de Heidegger, sobre todo si se lo compara con su notable hermenéutica de la facticidad existencial y con la sugerente lectura de la filosofía europea que emprende al hilo de la perspectiva onto-teológica. Esta es, dicho sea de paso, mi propia impresión. Tiendo a pensar, en efecto, que este recurso a lo divino peca por exceso y por defecto desde el punto de vista de la fenomenología (cuyo gesto fundacional Heidegger celebró y cuyo método no constructivo, que más bien va a la zaga -claro que interpretativamente- del mostrarse de los fenómenos, nunca abandonó ni dejó de practicar). El defecto es el de Ser y tiempo, en donde Heidegger se conduce agnóstica o ateísticamente, siendo que una mejor descripción de los hechos religiosos se ve llevada a admitir en la existencia humana la raíz tanto de la irreligión como de la religión, y no de la una en perjuicio de la otra. El exceso, a su vez, es el de obras como las Aportes a la filosofía, la Carta sobre el humanismo y Tiempo y ser, en las cuales Heidegger coloca las bases de un pensamiento que se refiere a Dios idiosincrásica, profusa, casi incontinentemente, en el entendido de que una filosofía más precisa, ceñida y comunicable debiera distinguir rigurosamente entre el análisis del problema de Dios (que ha de señalar cómo es que Dios aparece, o puede aparecer, a la luz de la existencia y de la historia humanas y en el conjunto de las cosas del universo) y su explicación (que es el intento de fundamentar el mejor derecho epistémico de la religión o la irreligión y que, en caso de tenerlo la primera, investiga cuál sería en consecuencia el concepto más consistente del teísmo y cuáles los argumentos más razonables que este podría argüir en favor de la existencia de la divinidad) (1). Con todo, hay que admitir que semejante valoración pudiera proceder con demasiada rapidez, dejando en la penumbra una

(1) Lo expuesto hasta aquí es síntesis de Solari, Enzo, "El problema de Dios según Heidegger”, en Cuadernos Salmantinos de Filosofía 35 (2008), en curso de publicación. 
mejor explicitación del sentido de la cuestión de Dios en el pensamiento de Heidegger. Conviene demorarse en la fijación de tal sentido, más en particular, para que la valoración del peculiar recurso heideggeriano a lo divino sea tan ajustada como sea posible. Si debe hallarse una apropiada dirección interpretativa para echar luz sobre la divinidad que Heidegger invoca, es porque incluso el juicio de que tal invocación posee un pobre rendimiento intelectivo no excusa la labor previa de aplicarle alguna pauta significativa.

Esto mismo pretendió un discípulo de Heidegger, Hans Jonas, quien, atribuyendo también poca hondura intelectiva y escaso valor religioso al theós de Heidegger, no dejó de esforzarse en comprender su significado más propio. Según Jonas, tal significado puede esclarecerse a la luz del gnosticismo, sobre todo si se atiende a la analítica heideggeriana de la existencia. Esto no implica desconocer la existencia de fases en el pensamiento de Heidegger, olvidando que su filosofía de los años 20 es distinta de la que sigue a la Kehre (2). De hecho, Jonas piensa que la posterior insistencia heideggeriana en el último Dios, con su aire oracular y profético, sería en todo caso ajena a la teología cristiana y, en este sentido, esencialmente pagana (3). Por otra parte, así como a Jonas le parece iluminador leer a Heidegger a partir del gnosticismo, se le antoja también productiva la óptica heideggeriana para desentrañar las claves de sentido más profundas de los sistemas gnósticos. Jonas dice que su misma biografía intelectual es perfecta prueba del círculo hermenéutico de que habla Ser y tiempo, al marchar primero desde Heidegger hacia el gnosticismo para luego volver desde el gnosticismo hasta Heidegger, proceso en el cual cada término derrama luz sobre el otro, aclarándose al cabo ambos recíprocamente (4). La filosofía de Heidegger, en especial cuando analiza las estructuras formales de la existencia humana, guardaría alguna analogía para con el antiguo gnosticismo que se desplegó entre los siglos II y IV d. C. Veámoslo más detalladamente.

Como es sabido, Jonas procede de acuerdo al método fenomenológico con el objeto de hallar el tipo fundamental del mito gnóstico:

“si hemos conseguido esto, poseemos en el 'arquetipo' mitológico que hemos obtenido (por decirlo así, la forma pura que incluye la necesaria variabilidad en las realizaciones materiales) el principio sintético que buscábamos para la multiplicidad de objetivaciones míticas en el ámbito gnóstico de interpretación" (5).

Con tal procedimiento fenomenológico, Jonas cree descubrir la mencionada analogía entre Heidegger y el gnosticismo (6). En Heidegger, dice, el básico encontrarse del Dasein no es sino angustia del mundo, y su tendencia dominante, una

(2) Dice por ej.: "hablo aquí de Sein und Zeit, no del último Heidegger, que sin duda no es "existencialista": La religión gnóstica. El mensaje del Dios extraño y los comienzos del cristianismo (trad. M. Gutiérrez, Madrid, Siruela 2000), p. 386.

(3) Vid. Jonas, Hans, Memorias (trad. I. Giner, Madrid, Losada 2005), p. 330.

(4) Vid. Jonas (n. 2), pp. 337-339.

(5) Jonas, Hans, La gnosis y el espíritu de la antigüedad tardía. Vol. 2: De la mitología a la filosofía mística (trad. J. Navarro, Valencia, Institució Alfons El Magnànim 2000), p. 57.

(6) Vid. Jonas (n. 5), p. 69, y pp. 337 y 342 (n. 2). 
tendencia de desmundanización. Así, el análisis existencial no termina en la mera correlación 'Dasein-mundo', sino que se prolonga en la admisión de una caída de la existencia humana y de su absorción por el mundo, de su extrañamiento y la consiguiente inhospitalidad mundanal (7). Para Heidegger, dice Jonas,

“[...] la esencia no mundana del Dasein, perdida en el mundo (libertad acósmica bajo la necesidad cósmica), se torna consciente angustiosamente de su originaria extrañeza al mundo. La inhospitalidad se convierte en angustia del mundo" (8).

Y lo decisivo, asegura, es que este mismo es el principio unitario "para la multiplicidad de fenómenos de la mitología gnóstica" (9).

Efectivamente, un angustioso extrañamiento o, en otros términos, la experiencia nihilista de estar hundido en un universo que en el fondo nada es y nada vale, es para Jonas característica tanto de los sistemas gnósticos como de la filosofía de Heidegger y, en general, del moderno existencialismo. En ambos casos habría en la base una radical experiencia nihilista. El nihilismo gnóstico y el existencialista responden a dos situaciones muy distintas y temporalmente distanciadas, pero que sin embargo serían comparables. El nihilismo moderno tiene raíces ya en el siglo XVII. Pascal diagnostica la soledad humana ante el universo, cuando dice que el hombre como res extensa es una simple caña en el universo, pero que como res cogitans está sobre el universo: este no lo conoce, él en cambio sí. Luego Nietzsche anuncia del modo más claro posible el nihilismo, la vivencia no solo de pérdida, abandono y temor ante el universo, sino de que la naturaleza universal resulta indiferente y sin valor propio, ya que los valores solo penden de la voluntad (que no de la intelectual visión) humana (10). Dios en la modernidad, aunque siga siendo considerado como el creador de todo, es siempre y solo el gran desconocido (deus absconditus, ágnostos theós). Lo único que habla de Dios en el universo es la inmensidad, lo cuantitativo, la extensión, "y lo que la magnitud puede comunicar es poder" (11). Dios, aun existiendo, es inescrutable. Por ello el hombre no tiene referencias estables para orientar su vida. El ser humano es solo voluntad y poder, y, al no tener ser fijo y sustancial, es homo absconditus. Para Jonas, “el poder se convierte así en el aspecto

(7) Vid. Jonas (n. 5), pp. 69-70.

(8) Jonas (n. 5), p. 70. De ahí provienen, dice además, el odio al mundo, la huida de él y el impulso a redimirlo.

(9) Jonas (n. 5), p. 69. Dicho sea de paso, Jonas agrega que en la gnosis habría una esencial (y errónea) objetivación: "phôs - skótos, theós - kósmos, pneûma - psykhé son puestos como polos alternativos que se mantienen (y esto es decisivo para todo este dualismo objetual) en la misma esfera de intuitividad y cualificabilidad objetuales, y que por tanto conforman entre sí una relación de posible exclusión: de tal modo que uno puede aparecer exclusivamente en el lugar del otro, o visto subjetivamente: que desde este se puede avanzar hacia aquel (al margen de que esto sea representado a la manera del ánodos, o de la metamórphosis, o de la superación poderosa de uno por el otro o de cualquier otra manera)" (pp. 70-71). Jonas llama a esta errónea interpretación objetivadora de la tendencia desmundanizadora de la existencia, “"mundanización' de la tendencia de desmundanización" (p. 71).

(10) Vid. Jonas (n. 2), pp. 339-341.

(11) Jonas (n. 2), p. 341. 
principal del cosmos, y su esencia interior es la ignorancia (agnosía)" (12). La esencia del existencialismo es, como se ve, cierta dualidad entre hombre y mundo, una pérdida del cosmos como algo afín, familiar: un acosmismo antropológico.

No cabe duda de que esto es condicionado por la ciencia física moderna. Como tampoco de que ella no es la única capaz de crear tal condición. Si es verdad que el nihilismo cósmico es la condición del existencialismo dualista, también lo es que dicho nihilismo - sin la compañía de la moderna física- caracterizó también a los movimientos gnósticos "que proliferaron en los tres primeros siglos, profundamente agitados, de la era cristiana, en el mundo helenístico del Imperio romano y más allá de sus fronteras orientales" (13). Jonas apunta una afinidad de la situación cultural del mundo grecorromano de los primeros siglos cristianos con la situación moderna, como si nosotros mismos viviéramos ahora en la época de los primeros césares. Esta familiaridad se monta -es evidente- sobre sendas diferencias: imaginación metafísica desatada del gnosticismo versus desilusión metafísica del existencialismo, y religiosidad de aquel versus ateísmo postcristiano de este (14). Pero el gnosticismo es también un dualismo radical entre hombre y mundo y entre mundo y Dios. Esta dualidad es fundamento lógico de aquella, y la primera es fundamento psicológico de la segunda: "en esta configuración de tres términos -hombre, mundo, Dios-, el hombre y Dios están unidos en contraposición al mundo, pero, de hecho y a pesar de esta unión esencial, se encuentran separados precisamente por el mundo" (15), de lo que resulta un sentimiento fundamental de desunión absoluta respecto del mundo en que el hombre mora.

Según la teología gnóstica, Dios es transmundano, otro, no revelado, incognoscible para el hombre (que ni siquiera lo puede conocer por medio de analogías mundanas), y extraño para el mundo y sin repercusión sobre el universo físico (16). Según la cosmología gnóstica, el mundo no es creación divina, sino hechura "de un principio inferior cuya ley ejecuta", principio ora personal, ora impersonal, que conserva del verdadero Dios

“el poder para actuar, pero para actuar ciegamente, sin conocimiento o benevolencia. De este modo el demiurgo creó el mundo a partir de la ignorancia o la pasión" (17).

El cosmos es esencialmente poder, pero el poder de un orden extraño, necesario y vengativo:

"lejos de ser caos, la creación del demiurgo, a pesar de su desconocimiento de la luz, es todavía un sistema de ley [...] El lógos cósmico de los estoicos, que fue identificado con la providencia, es reemplazado por la heimarméne, opresivo destino cósmico" (18).

(12) Jonas (n. 2), p. 344.

(13) Jonas (n. 2), p. 342.

(14) Vid. Jonas (n. 2), pp. 342-343.

(15) Jonas (n. 2), p. 343.

(16) Vid. Jonas (n. 2), pp. 343-344.

(17) Jonas (n. 2), p. 344.

(18) Jonas (n. 2), p. 345. 
Incluso las esferas celestes, otrora alabadas como divinas, "dejan de ser afines al hombre y se convierten en tiranas: se temen pero también se desprecian, porque son inferiores al hombre" (19). Según la antropología gnóstica, en palabras de Jonas,

“[...] el yo interno del hombre, el pneûma ('espíritu' en contraste con 'alma' = psykhé) no es parte del mundo [...], sino que es, dentro de ese mundo, tan absolutamente transcendente y desconocido por todas las categorías mundanas como lo es su equivalente transmundano, el Dios desconocido del exterior [...] El hombre no debe lealtad a quienquiera que haya creado el mundo, ni tampoco respeto a su obra" (20).

Convive, pues, la demonización del universo con la transcendencia del yo acósmico (11). Y de allí mismo se deriva el papel absolutamente decisivo del conocimiento: "la esencia del hombre es el conocimiento -conocimiento de sí y de Dios-, y este hecho determina su situación como la situación del conocimiento potencial en medio del desconocimiento, o la de la luz en medio de la oscuridad, relación que se encuentra en el fondo de su condición de extraño, carente de compañía en la oscura vastedad del universo" (22).

Es cierto: el hombre gnóstico se siente abandonado, sometido a la extraña necesidad cósmica, y por ello tiene miedo y temor: "el temor como respuesta del alma a su ser en el mundo es un tema recurrente en la literatura gnóstica" (23). Este temor es a la vez -en cuanto "temor interno de la alienación y del autoextrañamiento" (24)- el despertar de su borrachera o sueño mundanal. Profundizar a través del conocimiento (gnôsis) en tal alienación y autoextrañamiento -no pretender la integración en el lógos cósmico como el estoico- es lo que libera al hombre de la esclavitud. El yo interior se libera si el hombre supera el poder del mundo mediante algún otro poder. El poder del mundo es superado, de una parte, por medio del poder del Salvador, "que se introduce, desde el exterior, en el sistema cerrado de este, y, de otra, por medio del poder del 'conocimiento' traído por dicho Salvador, el cual, como arma mágica, vence a la fuerza de los planetas y abre para el alma un camino a través de sus obstáculos" (25).

Ahora bien. Así como toda la ley (natural, política y moral) queda subvertida en el antinomismo gnóstico, algo semejante ocurre -aunque de maneras más sutiles y reflexivas- con el existencialismo. Nietzsche diagnostica el nihilismo moderno diciendo: 'Dios ha muerto', lo que no solo alcanza al Dios cristiano o a los valores

(19) Jonas (n. 2), p. 345.

(20) Jonas (n. 2), p. 344.

(21) Vid. Jonas (n. 2), p. 347.

(22) Jonas (n. 2), p. 344.

(23) Jonas (n. 2), p. 346.

(24) Jonas (n. 2), p. 346.

(25) Jonas (n. 2), p. 346. Jonas subraya aquí la importancia del repudio (en la antigüedad postclásica) de la doctrina clásica del 'todo y las partes', sobre todo en el plano social y político, pues el hombre de esa época se siente parte insignificante del todo social (del Imperio), todo que le resulta totalmente extraño: "la aspiración del ente individual gnóstico no era 'hacer un papel' en este todo, sino, en lenguaje existencialista, "existir de manera auténtica'” (p. 347). 
morales más elevados, sino que también envuelve la falta de vigencia del mundo suprasensible en general (26). El nihilismo gnóstico, en cambio, no abandona la transcendencia -no dice que Dios haya muerto-:

“el Dios transmundano representa esta transcendencia de la forma más radical. En él el más allá absoluto hace señales que atraviesan las envolventes cortezas cósmicas [...] El Dios gnóstico, tan diferente del demiurgo, es el totalmente diferente, el otro, el desconocido. Igual que su equivalente humano interno, el yo acósmico o pneûma, cuya naturaleza oculta también se revela a sí misma solo en la experiencia negativa de la otredad, de la no identificación, y de la indefinible y rechazada libertad, este Dios tiene más de nihil que de ens en su concepto" (27).

Esta es la razón por la que ninguna ley -natural, política o moral- emana de tal Dios. No es difícil percatarse del parentesco de estas expresiones tan antinómicas con las de Sartre (parentesco, no identidad, pues otra cosa para este autor es la desesperación que afecta a la libertad humana). De hecho, en el gnosticismo puede advertirse el paso desde un cierto subjetivismo moral (nada es bueno o malo, las cosas son indiferentes, solo la opinión humana las califica y de ella depende la ley moral) hacia un argumento metafísico que hace de la ley tanto natural como moral partes del nómos esclavizante emanado del demiurgo. La libertad auténtica del yo no incumbe al alma sino al espíritu humano, a esa chispa extraña al mundo y no definible como naturaleza (28).

También cabe comparar el antinomismo gnóstico con la tesis que Heidegger expone en su Carta sobre el Humanismo, según la cual la definición del hombre como animal rationale lo sitúa demasiado bajo, no tanto por hacer de él un animal como por ponerlo en una misma escala natural (la de la animalidad) con otros seres animados (no solo las bestias), es decir, por hacer de él una naturaleza definible y someter así su existencia a un orden esencial objetivo y legal. Dice Jonas:

“en esta concepción de una existencia transesencial, 'que se proyecta libremente a sí misma', encuentro una relación con el concepto gnóstico de la negatividad transfísica del pneûma. Lo que no tiene naturaleza no tiene norma [...] El hombre físico no puede hacer nada mejor que cumplir con el código de una ley y esforzarse por ser justo, es decir, por 'ajustarse' correctamente al orden establecido, y así hacer la parte proporcional que le corresponde en el esquema cósmico. Sin embargo, el pneumatikós, el hombre 'espiritual', que no pertenece a ningún esquema objetivo, se encuentra por encima de la ley, más allá del bien y del mal, y es una ley en sí mismo por el poder de su 'conocimiento"" (29).

(26) Vid. Jonas (n. 2), pp. 348-349.

(27) Jonas (n. 2), p. 349.

(28) Vid. Jonas (n. 2), pp. 291-292 y 349-350.

(29) Jonas (n. 2), pp. 350-351. 
El poder salvífico de esta cognición espiritual señala rasgos característicos de los sistemas gnósticos como el dualismo, la tensión escatológica y la irreversibilidad de la dirección desde el pasado hacia el futuro, rasgos todos no del ser sino del acontecer. En particular, añade Jonas, el humano 'haber sido arrojado' de que habla el gnosticismo recuerda no solamente a Pascal (el hombre proyectado a la infinita inmensidad espacial), sino también a Heidegger y a su idea de Geworfenheit:

“el término, hasta donde alcanzo a ver, es originalmente gnóstico. En la literatura mandea esta es una frase común: la vida ha sido arrojada al mundo, la luz a la oscuridad, el alma al cuerpo" (30).

El conocimiento, en las fórmulas valentinianas, no puede morar en el presente, sino en el pasado de donde venimos y en el futuro hacia donde vamos, "y el presente es solo el momento mismo de la gnôsis, la peripecia que va de uno a otro en una crisis suprema del ahora escatológico" (31). Claro que el gnóstico agrega algo ajeno al existencialista: que el hombre viene de lo eterno y tiene su meta en lo eterno. En Ser y tiempo, enfatiza Jonas, en vez de categorías objetivas à la Kant, lo que hay son categorías de realización, 'existenciales', que son "estructuras funcionales del movimiento activo del tiempo interior en virtud del cual se mantiene un 'mundo' y se origina el yo como acontecimiento continuo" (32). Los existenciales casi no tienen presente, "al menos por lo que se refiere a modos de existencia 'genuina' o 'auténtica" (33). Unos son existenciales de pasado: facticidad, necesidad, llegar a ser, haber sido arrojado, culpabilidad. Otros, existenciales de futuro: existencia, adelantarse al propio presente, anticipación a la muerte, cuidado y resolución. El único presente genuino es el de la situación: "este presente aparece como un destello, por así decir, a la luz de la decisión, cuando el 'futuro' proyectado reacciona sobre el 'pasado' dado (Geworfenheit) y en este encuentro se constituye lo que Heidegger llama el 'momento' (Augenblick)" (34). Pero en general, el presente es "una especie de inactividad del ser", un abandono a la habladuría, a la curiosidad y al anonimato de la caída (Verfallenheit), siendo esta el existencial que incumbe al presente deficiente. Desde el punto de vista de las cosas ocurre lo mismo, dice Jonas: en tanto que zuhanden se inscriben en la dinámica existencial de pasado-futuro, mientras que solo en tanto que vorhanden (modo neutralizado y derivativo de considerarlas) están presentes. Vorhandenheit es de hecho el equivalente objetivo del existencial Verfallenheit: "según esta consideración teórica, a la naturaleza no le queda otra condición que esta, la de un modo deficiente del ser, y la relación que queda así objetivada es un modo deficiente de existir, su defección de la futuridad del 'cuidado' en beneficio del presente espurio de una mera curiosidad espectadora" (35). Según Jonas, esta depreciación de la idea de naturaleza, aunque conectada con la física moderna, algo tiene en común con el me-

(30) Jonas (n. 2), p. 351.

(31) Jonas (n. 2), p. 352.

(32) Jonas (n. 2), p. 352.

(33) Jonas (n. 2), p. 353.

(34) Jonas (n. 2), p. 353.

(35) Jonas (n. 2), p. 354. 
nosprecio gnóstico de la naturaleza: "ninguna filosofía ha mostrado nunca menos interés por la naturaleza que el existencialismo, que niega a dicha naturaleza cualquier vestigio de dignidad" (36). Con Heidegger, así, acaba el privilegio de la theoría platónica, la contemplación de las ideas, de lo eterno:

"el ser inmutable es eterno presente, al cual puede acceder la contemplación en la breve duración del presente temporal. Así, es la eternidad, no el tiempo, lo que concede un presente y le otorga un estado propio en el flujo del tiempo. Por otro lado, será la pérdida de la eternidad la que responda de la pérdida de un presente genuino. Tal pérdida de eternidad es la desaparición del mundo de las ideas y los ideales en la cual Heidegger ve el verdadero significado del 'Dios ha muerto' de Nietzsche: en otras palabras, la victoria absoluta del nominalismo sobre el realismo [...] Si los valores no son contemplados como ser (como lo Bueno y lo Bello de Platón), sino que es la voluntad la que los propone como proyecto, la existencia sin duda está comprometida a la futuridad constante, con la muerte como meta; y una futura resolución meramente formal, sin un nómos para dicha resolución, se convierte en un proyecto que va de la nada a la nada" (37).

La conclusión de Jonas es que no hay una diferencia esencial entre el dualismo adherido a la experiencia nihilista del gnosticismo y el que es típico de existencialismos como el de Heidegger:

“una vez más, nuestra investigación nos lleva de vuelta al dualismo entre el hombre y la Physis, como aprendizaje metafísico de la situación nihilista. No existe una diferencia fundamental entre el dualismo gnóstico y el existencialista: el hombre gnóstico es arrojado a una naturaleza antagonista, antidivina y, por tanto, antihumana; el hombre moderno, a una naturaleza indiferente. Solo el último caso representa el vacío absoluto, el verdadero pozo sin fondo. En la concepción gnóstica, lo hostil, lo demoníaco, es todavía antropomórfico, familiar incluso dentro de su diferencia, y el contraste otorga una dirección a la existencia: una dirección negativa, sin duda, pero dirección al fin, que cuenta con la sanción de la transcendencia negativa de la cual la positividad del mundo es el homólogo cualitativo. La naturaleza indiferente de la ciencia moderna ni siquiera cuenta con esta cualidad antagonista, y de una naturaleza así no es posible obtener ninguna dirección. Esto hace que el nihilismo moderno sea infinitamente más radical y desesperado de lo que el nihilismo gnóstico

(36) Jonas (n. 2), p. 354.

(37) Jonas (n. 2), p. 355.

(38) Jonas (n. 2), pp. 355-356.

(39) Jonas (n. 2), pp. 356-357. Sea de ello lo que fuere, Jonas termina aventurando incluso algún proyecto para remediar el aislamiento universal del ser humano al que conducen el gnosticismo y el existencialismo: "la fractura entre el hombre y la realidad total se encuentra en el fondo del nihilismo. La falta de lógica de la ruptura, es decir, de un dualismo sin metafísica, no disminuye la realidad de este hecho [...] La filosofía deberá descubrir si existe una tercera vía para esta situación, una vía gracias a la cual se pueda evitar la grieta dualista, y que sin embargo conserve el suficiente dualismo como para mantener la humanidad del hombre" (p. 357). 
podría ser nunca a pesar de su terror pánico hacia el mundo y su desprecio desafiante hacia las leyes de este" (38).

Con todo, dice aún Jonas, esta esencial semejanza entre el dualismo gnóstico y el existencialista no esconde que este último sea menos coherente que aquel, justamente por postular una naturaleza no demoníaca sino indiferente:

"¿qué sucede, sin embargo, con una naturaleza indiferente que, a pesar de dicha indiferencia, contiene en su interior aquello por lo cual su propio ser crea una diferencia? La frase que hace referencia a haber sido arrojado a una naturaleza indiferente es remanente de una metafísica dualista, y un enfoque no metafísico no tiene derecho a utilizarla. ¿Qué es el acto de arrojar sin un sujeto que arroja, y sin un más allá desde el cual se puso en marcha? [...] ¿No es verdad que esta paradoja plantea algunas dudas sobre el concepto mismo de una naturaleza indiferente, esa abstracción de la ciencia física? [...] Como producto de lo indiferente, su ser [el del hombre] debe ser también indiferente" [...] Sin embargo, si la profunda reacción de Heidegger es correcta -la que defiende que, al contemplar nuestra finitud, nos preocupamos no solo de si existimos sino de cómo existimos-, el mero hecho de que exista una solicitud suprema, en cualquier parte del mundo, debería también cualificar a la totalidad que acoge ese hecho [...]" (39).

En suma: la tesis que Jonas insinúa, que el pensamiento de Heidgeger respira un aire pagano afín al del gnosticismo, se basa, más incluso que en su enigmática apelación a lo divino, en la comparación detallada de la analítica heideggeriana de la existencia con la antropología y la cosmología de la actitud gnóstica. El dualismo entre el ser humano y el mundo y la básica experiencia de nihilidad son las notas sobre las que se establecería la fina proximidad y analogía de dicha filosofía con los sistemas gnósticos. Creo, sin embargo, que deben ponerse objeciones a esta postura. Para ello hay que comenzar precisando el alcance de los términos 'gnosis' y 'gnosticismo', cuyo uso a veces se entrevera sin discernimiento. No basta con decir como Jonas, por acertado que sea, que en el fondo ambos suponen el angustioso arrojamiento del ser humano en el mundo (40) o actitudes como el odio contra la carne y el anticosmismo (41), o que en su origen quizá judeo-helenístico jugó un papel determinante cierta interpretación esotérica del Génesis a la luz del Timeo platónico así como alguna recepción del dualismo indo-iranio entre el bien y el mal (42). De

(40) Cf. los textos gnósticos que cita Brague, Rémi, y su argumentación contraria a equipararlos con la Geworfenheit heideggeriana, en La sagesse du monde. Histoire de l'expérience humaine de l'univers (Paris, Fayard 1999), pp. 99-104 y 314.

(41) Cf. respectivamente las interpretaciones de Peterson, Erik, "El odio contra la carne", en Tratados teológicos (trad. A. Andreu, Madrid, Cristiandad 1966), pp. 235-242, y del propio Brague (n. 40), pp. 93-98, 104-105 y 122-125.

(42) Cf. Widengren, Geo, Fenomenología de la religión (trad. A. Alemany, Madrid, Cristiandad 1975), pp. 443-475; Piñero, Antonio, Cristianismos derrotados. ¿Cuál fue el pensamiento de los primeros cristianos heréticos y heterodoxos? (Madrid, Edaf 2007), pp. 92-95, y Piñero, Antonio y Montserrat, José, "Introducción general", en A. Piñero (ed.), Textos gnósticos. Biblioteca de NagHammadi Vol. 1: Tratados filosóficos y cosmológicos (Madrid, Trotta ${ }^{3} 2007$ ), pp. 95-106. 
hecho, la morosa investigación histórico-filológica en torno al gnosticismo desarrollada en las últimas décadas, tan marcada por el descubrimiento y la difusión de la biblioteca de Nag-Hammadi, tiende a distanciarse del método fuertemente existencial y hermenéutico adoptado por Jonas. Para ser justos, eso sí, hay que decir que el propio Jonas ha intentado superar ese global estilo expositivo, precisando más las cosas. Por ejemplo, cuando ensaya este resumen del contenido y los problemas del mito gnóstico en su tipo fundamental:

"[...] hemos encontrado un crudo dualismo religioso entre Dios y el mundo y un rasgo constante de abandono del mundo. El cosmos es tinieblas, producto de una caída, con un 'dios del mundo' propio, su creador (el demiurgo), que no es el Dios auténtico, sino el principio del cosmos alejado de Dios, la personificación de la esencia del mundo. Frente a él se halla el Dios auténtico, la luz frente a las tinieblas del mundo, la bondad frente a la 'justicia' del dios del mundo, no solo supramundanamente, sino lo no mundano, lo antimundano en absoluto. Su reino comienza donde acaba todo lo cósmico, completamente fuera, más allá: concepto del más allá como negatividad del mundo en absoluto. El ser humano, 'arrojado' en el cosmos como en una potencia extraña y hostil, abandonado a su hechizo ineluctable: imágenes del vagar, del aturdimiento, de la embriaguez, de la extrañeza, del estar desterrado de la patria, del esclavizamiento bajo el hechizo del mundo. Este hechizo, que mantiene cerrado todo lo que se encuentra debajo de él y afirma el cosmos como ámbito concluso y autónomo frente a Dios, es ejercido por un sistema cósmico de poder propio bajo el mando supremo del demiurgo: las potencias celestes (heimarméne), la encarnación mítica del poder de coacción de lo mundano. (De aquí resulta la separación de la 'heimarméne' mundana y la 'providencia' soteriológica que parte del Dios supremo.) El ser humano está sometido a esta heimarméne no solo con su cuerpo, sino también con su psykhé, pues esta es un producto de la esencia del mundo (depravación del concepto de psykhé). De este modo, el mundo se extiende hasta el interior del ser humano. Lo único no mundano en el ser humano es un núcleo de 'humanidad originaria', 'revestido' por la esencia del mundo con la psykhé en la caída pretemporal desde el reino de la luz (especulación del ánthropos). Tomado sustancialmente, se trata del pneûma. Este necesita ser redimido del mundo. Si hay ser en el mundo (esclavización que aleja de Dios bajo la tiranía de la esencia del mundo), también hay redención: ruptura del hechizo del mundo y redeificación. El principio real de tal aniquilación de lo mundano es Dios. Su fuerza desmundanizadora se realiza en el mito escatológico como definitiva redisolución objetiva de todo el cosmos. Para el individuo, la redención (en tanto que ruptura del hechizo del mundo) significa también necesariamente la disolución de la psykhé, que no es otra cosa que un constitutivo de las potencias del mundo. El principio real de esta aniquilación redentora de la psykhé es (visto en cuanto a su función ejecutiva) el pneûma que produce la reunificación con Dios. Lo que es Dios para el cosmos, eso es el pneûma para la psykhé individual. Así, pues, tenemos ante nosotros un sistema objetual de las magnitudes elementales kósmos - psykhé - pneûma - 
theós, con el punto de cambio de la redención situado en medio de ellas [...] Esta 'imagen del mundo' no es tanto la imagen de un ser como de un acontecer, de una historia que tiene que hacer efectivo todo lo que la expectativa ha puesto en su construcción: está proyectada esencialmente hacia el futuro, hacia el futuro absoluto, es decir, escatológicamente" (43).

Esta síntesis es confirmada por otras provenientes de especialistas en el estudio de los sistemas gnósticos. Por ejemplo, en el coloquio de Messina (de 1966) también se quiso ceñir mejor los términos involucrados. Allí se propuso determinar a la gnosis como un "conocimiento de los misterios divinos reservado a una élite", y al gnosticismo según la siguiente fórmula:

"hay en el hombre una centella divina procedente del mundo superior, caída en este mundo sometido al destino, al nacimiento y a la muerte; esta centella debe ser despertada por la contraparte divina de su yo interior para ser, finalmente, reintegrada a su origen. Frente a otras concepciones de la degradación de lo divino, esta se funda ontológicamente en un concepto particular de 'degradación', cuya periferia (con frecuencia llamada Sophía o Énnoia) debía entrar fatalmente en crisis y -de modo indirecto- dar origen a este mundo, del que, por otra parte, no puede desinteresarse, puesto que ha de recuperar el Pneûma que en él se encuentra. (Concepción dualista sobre fondo monista que se expresa por medio de un doble movimiento de degradación y de reintegración) [...] No toda gnosis es gnosticismo, sino tan solo aquella que, en el sentido ya expresado, implica la idea de una connaturalidad divina de la centella que debe ser reanimada y reintegrada; esta gnosis del gnosticismo comporta la identidad divina del cognoscente (el gnóstico), de lo conocido (la substancia divina de suyo transcendente) y del medio por el cual conoce (la gnosis como facultad divina implícita que debe ser despertada y actuada)" (44).

Conviene añadir que, en medio de toda su diversidad, los mitos gnósticos se identifican por multiplicar los entes (con armas metafísicas y objetivos religiosos) casi hasta el agotamiento, barrocamente, buscando el necesario modelo de este mundo sensible y penosamente mal fabricado en otro mundo superior, puramente espiritual y sin mácula, del que aquel sería sombra y trasunto. De ahí su empeño por hallar una explicación a la maldad de este universo corpóreo, que ha de tener su origen en el otro mundo, el espiritual, sin por ello comprometer la grandeza del

(43) Jonas (n. 5), pp. 67-69. Otro resumen del núcleo gnóstico ofrece Jonas en "Gnosticism”, en D.

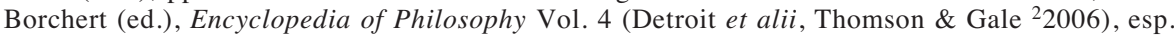
pp. 98-103.

(44) Citado por U. Bianchi, Le Origini dello gnosticismo. Colloquio di Messina (Leiden $\left.{ }^{2} 1970\right)$, pp. XX-XXI, citado a su vez por Montserrat, José (int., trad. y n.), Los gnósticos Vol. 1 (Madrid, Gredos 1983), pp. 8-9. Véanse las precisiones aún mayores aportadas por Piñero y Montserrat (n. 42), pp. 33-37, y por Montserrat, José (trad. y com.), "Introducción general", en El Evangelio de Judas (Madrid et alii, EDAF 2006), pp. 25-35. 
supremo principio divino (45). Doresse, en el mismo sentido y combatiendo la idea de Harnack según la cual el gnosticismo habría sido una 'aguda helenización del cristianismo', propone como principio definitorio el que entrega Plotino en En. II 9:

“Contra aquellos que afirman que el Demiurgo de este mundo es malo, y que el cosmos es malo' [...] Baste añadir [a esta excelente definición del gnosticismo] que, para explicar la situación del hombre en este mundo, los gnósticos suponen en cada uno de los elegidos la presencia de una chispa escondida, radicalmente extraña al cosmos, desprendida en algún momento pasado del mundo eterno de la deidad suprema, pero destinada a retornar algún día a su fuente original. La caída de esta chispa en el ámbito de las tinieblas podría ser consecuencia, al parecer, de una lucha entre las tinieblas y la luz o de un accidente ocurrido al producirse las emanaciones de lo alto; de una u otra de estas deficiencias nació un dios imperfecto y envidioso que, incapaz de proseguir la producción de jerarquías superiores, solo puede copiar torpemente los modelos, sacando de las tinieblas la sustancia de los cielos materiales esclavizados al Tiempo y al Destino, así como del hombre carnal en que se encuentra aprisionado el fuego que procede de lo alto. Antes de aniquilar este efímero mundo inferior, las entidades superiores tratan de rescatar los fragmentos de luz inmersos en el cosmos. Por mediación de unos salvadores buscan a los elegidos que, hasta ahora, han ido transmigrando de un cuerpo a otro en las profundidades de esta cárcel, comunicándoles la revelación de la Gnosis y en especial los ritos de los grandes bautismos por agua 'viva' que les permitirán volver de nuevo al inefable mundo superior" (46).

Otra propuesta, aún más precisa y escolar, de catalogación de los elementos fundamentales de los numerosos sistemas gnósticos es la que sigue:

“1. Existe un Dios Transcendente, al que se puede denominar Uno, Bien, Padre. 2. Esta divinidad es 'compleja' y se proyecta hacia fuera. Esta proyección constituye el Pléroma o Plenitud de la divinidad. 3. Dentro del Pléroma, uno de los

(45) "Para ellos se trataba de resolver el problema del mal. Si el mal está en la creación, su origen debe encontrarse en el acto creador; ahora bien, el Dios supremo es perfectamente bueno; no es, pues, Él el creador. Por el contrario, debe considerársele como la fuente primera de este conocimiento redentor con que Él gratifica a la jerarquía entera de los seres, incluidos los hombres 'gnósticos', para remediar la falta inicial del demiurgo y llevar así a cabo la obra de salvación": Gilson, Étienne, La filosofía en la Edad Media. Desde los orígenes patrísticos hasta el fin del siglo XIV (trad. A. Pacios y S. Caballero, Madrid, Gredos $\left.{ }^{2} 1965\right)$, p. 41. Al respecto, vid. también Widengren (n. 42), pp. 454-455.

(46) Doresse, Jean, "Gnosticismo", en C. J. Bleeker y G. Widengren (eds.), Historia Religionum. Manual de historia de las religiones Vol. 1 (trad. J. Valiente, Madrid, Cristiandad 1973), pp. 522-523. Vid. también del mismo, "La gnose", en H-Ch. Puech (ed.), Histoire des religions Vol. II (Paris, Gallimard 1972), pp. 421-422. La tesis de Harnack, en todo caso, no está enteramente sepultada; vid. por ej. Trevijano, Ramón, Patrología (Madrid, BAC ${ }^{3} 1998$ ), pp. 7476, y Strutwolf, Holger, "Die Gnosis im Rahmen der Antiken Philosophie", en P. Koslowski (ed.), Philosophische Religion. Gnosis zwischen Philosophie und Theologie (München, W. Fink 2006), pp. 9-12. 
eones divinos, denominado normalmente Sabiduría, cae en una suerte de lapso o pecado. 4. Ese lapso da origen a la materia primordial y al Demiurgo, diferentes del mundo del Pléroma, que es todo espíritu. 5. El Demiurgo, no el Dios Transcendente, es el que crea directamente el universo y el hombre. Utiliza, por un lado, la materia primordial $y$, por otro, las formas o ideas de las cosas que contempla en el Pléroma o en el ser de su madre, Sabiduría. 6. La parte mejor y más auténtica del ser humano es el espíritu. Este es como una centella o chispa divina porque procede del Dios Transcendente a través de Sabiduría y de la insuflación del Demiurgo. Su patria está en el cielo. 7. Esa chispa divina está encarcelada en la materia, es decir, en el cuerpo del hombre y en este mundo material. 8. La chispa divina debe retornar a donde procede. Esta vuelta constituye la salvación. 9. Un ser divino, denominado Redentor, Salvador o Revelador, desciende del Pléroma; con su revelación recuerda al hombre que posee esa centella; lo ilumina y lo instruye sobre el modo de hacerla retornar al ámbito del que procede. 10. La materia y el espíritu, el mundo de arriba y abajo son inconciliables. El que recibe la revelación y pretende salvarse debe rechazar todo lo material y corporal por medio de la ascesis" (47).

Dicho lo cual debe agregarse que, en su vertiente cristiana, el gnosticismo se caracteriza por concurrir con la doctrina salvífica del cristianismo eclesiástico de los primeros siglos, justo por tratar de dar una explicación plausible del mal en el mundo, de la situación del hombre en él y de la posibilidad de la redención. Pero hay diferencias: tales sistemas gnósticos son preponderantemente dualistas, pues separan a Dios del mundo, al espíritu de la materia y al bien del mal, siendo sin embargo a la vez predominantemente monistas en el fondo, ya que postulan una serie de emanaciones, emisiones o generaciones que llevan desde el Dios transcendente e inescrutable, pasando por un ámbito de seres intermedios, hasta el rastrero y malévolo mundo de la materia en cuya tenebrosa oscuridad están dolorosamente caídos los seres humanos. Junto a una escatología general (la liberadora aniquilación del entero universo material), el mito gnóstico postula una salvación personal que se consuma al momento de la muerte. Esta, que es imposible para los materiales (los hílicos, carnales o terrenos), les corresponde según un estadio intermedio (la denominada 'Ogdóada' inferior) a los imperfectos necesitados de purificación (los psíquicos), e incumbe en plenitud solamente a los perfectos (los pneumáticos), quienes -alcanzando finalmente el conocimiento salvífico, la gnôsis, luego de ser despertados por el llamado divino- ascienden y retornan a la Luz (48). Es lo que dice Ireneo a propósito de los gnósticos valentinianos:

(47) Piñero (n. 42), pp. 106-107. Muy semejante es el inventario de características principales del gnosticismo que ofrece McLachlan, Robert, "Gnosis/Gnostizismus", en G. Müller (ed.), Theologische Realenziklopädie Vol. 13 (Berlin, Walter de Gruyter 1984), pp. 536-537.

(48) Vid. en gral. Altaner, Berthold y Stuiber, Alfred, Patrologie. Leben, Schriften und Lehre der Kirchenväter (Freiburg et alii, Herder ${ }^{8} 1978$ ), p. 99. Sobre la escatología, vid. también los dos textos citados de Doresse (n. 46), pp. 542-546 y pp. 382 y 393-399, respectivamente, y Piñero y Montserrat, en Piñero (n. 42), pp. 72-89. Sobre las tres clases o razas de hombres, vid. Exc. Theod. 54-65 en la versión de Montserrat, José (int., trad. y n.), Los gnósticos Vol. 2 (Madrid, Gredos 1983), pp. 373-380. 
"la perfecta redención consiste para ellos en el mismo conocimiento de la grandeza indecible. Puesto que la deficiencia y la pasión han existido por la ignorancia, por medio del conocimiento es destruida toda substancia proveniente de aquella, de tal modo que es la gnosis redención del hombre interior [...] El hombre interior, el espiritual, es redimido por medio del conocimiento, y a los tales les basta con el conocimiento de todas las cosas. Esta es la verdadera redención" (49).

Por lo mismo, de acuerdo al testimonio de Clemente, los valentinianos aseguran que el bautismo no basta para la salvación, sino que se necesita sobre todo el conocimiento:

"ahora bien, no es solo la inmersión bautismal lo que salva, sino el conocimiento: quiénes éramos, qué hemos devenido; dónde estábamos, dónde hemos sido arrojados; hacia dónde nos apresuramos, de dónde somos redimidos; qué es la generación, qué la regeneración" (50).

Así, en tanto que dualismo mitigado o monarquiano (51), el gnosticismo cristiano parte de la afirmación (frecuentemente, una catarata de caracterizaciones negativas) de un único y supremo Dios desconocido. Es el Eón perfecto, Pre-Padre, PrePrincipio o Abismo de que habla Ireneo a la zaga del valentinismo (52). El indefinible, inescrutable, inconmensurable, invisible, eterno, inexpresable, innominable, ni corpóreo ni incorpóreo, ni grande ni pequeño, según las expresiones del Apócrifo de Juan de la escuela setiana (53). El inengendrado e inmortal, inalcanzable, incomprensible e insondable, el único bueno y enteramente perfecto al que se refiere el valentiniano Tratado Tripartito (54). Transcendiendo el cosmos, tal Dios no guarda ninguna relación con él; el único creador posible de este eón material tan malo y deficiente es un Demiurgo maligno o al menos desquiciado e ignorante (identificado con el Dios veterotestamentario) que se ha separado en los orígenes de aquel Dios ignoto:

“el mundo surgió por un error, pues quien lo creó quiso crearlo imperecedero e inmortal; fracasó y no obtuvo lo que esperaba, pues no tenía el mundo carácter imperecedero, ni tenía carácter imperecedero el que había hecho el mundo" (55).

(49) Adv. Haer. I 21,4, según la versión de Montserrat (n. 44), p. 195.

(50) Exc. Theod. 78,2, según la versión de Montserrat (n. 48), pp. 386-387.

(51) Sobre esta noción, vid. Eliade, Mircea y Couliano, Ioan, Diccionario de las religiones (trad. I. Arias, Barcelona et alii, Paidós 2007), pp. 147-149.

(52) Vid. Adv. Haer. I 1,1 en la versión de Montserrat (n. 44), p. 91.

(53) Vid. Apócrifo de Juan 2,26-4,10 según la versión de J. Montserrat, en Piñero (n. 42), pp. 236-237.

(54) Vid. Tratado Tripartito I 52,1-53,10 según la versión de F. García Bazán, en Piñero (n. 42), pp. $160-161$.

(55) Evangelio de Felipe (II,75,2-9), según la versión de F. Bermejo, en A. Piñero (ed.), Textos gnósticos. Biblioteca de Nag-Hammadi Vol. 2: Evangelios, Hechos, Cartas (Madrid, Trotta $\left.{ }^{3} 2007\right)$, pp. 43-44. 
Dentro de este mundo el hombre está arrojado, mas no completamente perdido, pues en su alma se halla encarcelado el espíritu, la misma esencia divina. Por ende, la salvación traída por Cristo (a veces, un 'salvador salvado' de su encadenamiento material y captura demoníaca) (56) es una ganancia no del acontecimiento de la cruz sino del conocimiento revelado en el Evangelio de dicha igualdad de naturaleza entre el hombre verdadero y el verdadero Dios. Esta salvación se alcanza en tanto en cuanto el elegido escuche la llamada -proveniente de lo Alto- o despierte recordando su ser más íntimo -que es espíritu, chispa de Dios-, y regrese a su origen supremo y fuente superior -la Luz divina- a través de la liberación de la mala materia mundanal y de su propia carne (57). Así, pues, la iluminación del conocimiento es condición de la resurrección, que no a la inversa (58). Y Cristo mismo es el iluminador, como lo confirman las expresiones valentinianas del Evangelio de la Verdad:

"este es el evangelio del que se busca, que se reveló a los que son perfectos por las misericordias del Padre, el misterio oculto, Jesús, el Cristo, por cuyo medio iluminó a los que estaban en la oscuridad a causa del olvido. Los ha iluminado y (les) ha mostrado un camino. El camino, sin embargo, es la verdad que les ha enseñado [...] De esta manera el que posee el conocimiento es de lo alto. Si es llamado, escucha, responde y se vuelve hacia quien lo llama para ascender hacia Él. Y sabe cómo se llama. Poseyendo el conocimiento hace la voluntad de quien lo ha llamado, quiere complacerle y recibe el reposo. Su nombre propio aparece. El que llegue a poseer el conocimiento de este modo sabe de dónde viene y a dónde va. Sabe como una persona que habiendo estado embriagada ha salido de su embriaguez, ha vuelto a sí misma y ha corregido lo que le es propio" (59).

Es evidente, pues, que el gnosticismo -tanto en general como en su versión cristiana- subordina la antropología y la cosmología a la teología y a su soteriología (60). Las características dualizaciones gnósticas responden siempre y solo a dicho componente religioso de salvación. Parece imposible acreditar que tanto la teología del Dios Transcendente y del Creador demiúrgico de la materia cuanto la soteriolo-

(56) Sobre la figura del 'redentor redimido' y la versión que da del mismo el 'Himno de la perla' (cf. Hechos de Tomás 108-113), el que (si hemos de creer a Reitzenstein) es una alegoría anterior al cristianismo, vid. Widengren (n. 42), pp. 159-161, 453-454 y (dispersamente) 466-475; el segundo texto citado de Doresse (n. 46), pp. 382 y 407; Eliade, Mircea, Historia de las creencias y de las ideas religiosas Vol. 2: De Gautama Buda al triunfo del cristianismo (trad. J. Valiente, Barcelona, Paidós 1999), pp. 435, 443-444 , 632 y 638-639; y como encuadre, Colpe, Carsten, "Gnosis II (Gnostizismus)", en Th. Klauser, E. Dassmann et alii (eds.), Reallexikon für Antike und Christentum Vol. 11 (Stuttgart, Hiersemann 1981), col. 564-572, esp. 570-572.

(57) Vid. en gral. Drobner, Hubertus, Lehrbuch der Patrologie (Frankfurt a. M. et alii, Peter Lang 22004), p. 144.

(58) Cf. García Bazán, Francisco, "En los comienzos de la filosofía cristiana: la actitud de los escritores eclesiásticos y de los gnósticos ante la filosofía", en Teología y vida XLIII (2002), p. 266.

(59) Evangelio de la Verdad 18,11-19 y 22,3-19, según la versión de F. García Bazán, en Piñero (n. 55), pp. 147-148 y 150. Sobre esta noción de la embriaguez o sueño, e incluso destierro y extranjería, del hombre en el mundo, de lo cual solo se despierta y regresa por la iluminación, vid. Widengren (n. 42), pp. 466-470.

(60) Por todos, vid. Piñero y Montserrat (n. 42), p. 79. 
gía de la gnôsis espiritual puedan ser consideradas como variables independientes dentro del sistema total del gnosticismo. Jonas lo reconoce al decir que el fundamento lógico de la dualidad 'hombre-mundo' es la dualidad 'mundo-Dios', y también al admitir que los gnósticos se definen, a través de una especulación recargadamente metafísica, por apelar religiosamente a cierta transcendencia teísta. Sin embargo, siendo este un dato elemental que hay que considerar con firmeza, Jonas tiende a olvidarlo o al menos a no considerarlo con la debida seriedad cuando compara elásticamente la analítica existencial de Heidegger con las nociones de 'mundo' y 'hombre' de los antiguos gnósticos. Entonces Jonas, argumentando a partir de la analítica existencial, hace del dualismo cósmico y antropológico el fundamento psicológico de ese otro dualismo teológico. Así, en los hechos y por una vía psicologizadora, parece tomar como variable independiente a la teología soteriológica, siendo que esta es más bien punto de partida y meta final del gnosticismo. De acuerdo con esta singular óptica, se seleccionan ciertos componentes sobre todo antropológicos y cosmológicos del gnosticismo, enteramente despojados de su nativa referencia religiosa a un Dios y a una economía transcendente de la salvación, para ponerlos luego en correlación con la antropología y la cosmología intramundanas e históricas que impregnan Ser y tiempo. Solamente de este modo pueden aparecer los rasgos comunes a la analítica existencial y a la actitud gnóstica que son el arrojamiento, la angustia, la materia mundanal como el sitio opaco de la habitual caída humana, la necesidad de despertar desde la vida mundanalmente enajenada a la vida propia o auténtica, el impulso decidido hacia el futuro como dirección restañadora de la actual situación perdida, la muerte como radical posibilidad, etc. Empero, basta un poco de precisión conceptual para ver, por ejemplo, que una noción como la de Geworfenheit carece de trasfondo teísta y salvífico y que por ende es incomparable con el humano arrojamiento de que hablan algunos textos gnósticos, que solo adquiere sentido a la luz del Abismo divino que está en su principio, de la creación del mundo material que es su habitáculo y de la liberación espiritual de su prisión mundana a través de la gnôsis. La cosa parece clara, y su constatación, constante: la teología soteriológica no es una variable independiente dentro del gnosticismo. Ya un antiguo crítico de los gnósticos como Plotino, al reprocharles la falta de examen de la virtud (areté) y la ausencia de una providencia divina (prónoia), no puede dejar de enfatizar estas carencias sobre el constante telón de fondo teológico del gnosticismo:

“porque la verdad es que de nada aprovecha decir: 'mira a Dios', si no se nos enseña además cómo mirar a Dios. ‘¿Qué me impide - dirá alguno- mirar a Dios y no abstenerme de ningún placer ni refrenar la cólera, acordándome, eso sí, del nombre 'Dios', pero siendo presa de todas las pasiones sin esforzarme, empero, por desarraigar ninguna de ellas?'. Pues bien, es la virtud la que, avanzando a su perfeccionamiento e implantada en el alma con ayuda de la sabiduría, nos muestra a Dios. Pero la mención de Dios sin la virtud verdadera no es más que un nombre. A su vez, despreciar el mundo, a los dioses que hay en él y las demás cosas bellas, no significa hacerse bueno [...] Puesto que desprecian a los dioses emparentados con los dioses inteligibles, ni siquiera conocen a los inteligibles más que de palabra. En efecto, negar 
que la providencia se extienda a los seres de acá o a un ser cualquiera, ¿cómo puede ser piadoso? ¿Cómo puede estar en consonancia con sus propios asertos? Pues ellos dicen a su vez que no hay providencia más que de ellos solos. ¿Cuándo? ¿Cuando estuvieron allá o incluso cuando están acá? Si cuando estuvieron allá, ¿cómo es que vinieron acá? Si cuando están acá, ¿cómo es que todavía siguen acá? El mismo Dios providente, ¿cómo negar que esté acá? ¿De dónde, si no, conocerá que ellos están acá? ¿Cómo sabrá que, estando ellos acá, no se olvidaron de él y se volvieron malos? [...] Pero sea que una providencia particular os viene de allá a vosotros, sea como vosotros queráis, en todo caso el mundo tiene parte en la providencia y no está desamparado ni se le dejará desamparado" (61).

En el otro extremo temporal, un estudioso contemporáneo de las escuelas gnósticas como Orbe constata que la teología y soteriología del gnosticismo no son ni pueden ser tratadas independientemente de la cosmología y la antropología, pues en los gnósticos se halla una 'pura teología', un 'teologizar en todos los campos' y, por ello, una antropología completamente orientada 'hacia la teología':

"en cuanto a las tradiciones heterodoxas, de base literaria comúnmente sobria (para el siglo II), no conviene llamarse a engaño. Traducido el mito a formas conceptuales hoy accesibles, ofrece en ocasiones (v. gr. entre ofitas y valentinianos) un material excepcionalmente denso; casi siempre, sin salir de la más pura teología [...] A los valentinianos (y ofitas) corresponde el mérito de la prioridad. De golpe, sin antecedentes que los anunciasen, se presentaron con absoluto dominio en todos los campos de la teología, y trazaron la Economía de la Salud, dentro de una línea continua. No se advierte entre ellos indecisión. Desde el principio seguros de sí, construyen con igual firmeza. Hayan o no largamente reflexionado sobre los lemas característicos de la Regla de fe, los teólogos valentinianos ofrecen un sistema complejo, definido hasta los perfiles últimos. A juzgar por escritos suyos parciales, eran capacísimos de estudiar puntos concretos. Admira por lo mismo con qué celeridad, penetración y madurez, lograron teologizar en todos los campos. No se improvisa visión tan simple, uniforme y armónica, sin reflexión igual para todos los dogmas [...] Para los grandes gnósticos, Cristo es el verdadero Ánthropos; mas no, paradójicamente, en lo humano, sino en lo divino, como Hombre de Luz, Hijo del

(61) Vid. En. II 9,15-16, según la versión que da J. Igal de Porfirio, Vida de Plotino / Plotino, Enéadas I-II (Madrid, Gredos 2001), pp. 528-529. A propósito de la ausencia de la virtud, Igal, citando a Puech, dice que "todo gnosticismo es siempre más o menos, en el fondo y en teoría, un 'amoralismo', pero un amoralismo 'ambivalente', que lo mismo puede desembocar en rigorismo ascético que en libertinaje. De ahí que unas sectas adoptaran una actitud y otras otra” (p. 527 n. 138). Y en cuanto a la divina providencia, ahora citando a Orbe, dice que no es cierto que los gnósticos prescindieran de ella: "las grandes familias heterodoxas jamás negaron la providencia superior, extensiva al universo, y, por ende, al mundo sensible. Solo negaron que se dejara sentir: a) siempre o desde siempre; b) por igual a todos [...] La providencia del Señor se ocupa de solo creyentes. Mas no porque excluya a otros, sino porque muchos se oponen a dejarse gobernar por Él culpablemente" (p. 515 n. 101). 
Theós Ágnostos. Ánthropos divino preexistente, concebido por Dios como paradigma (luminoso, espiritual) del hombre llamado a la salud. Los mitos de los Pléromas gnósticos (de ofitas, valentinianos, sethianos...) se emplean en orquestar a Cristo Ánthropos, ideal del 'hombre (espiritual)'. La historia del Kénoma traduce la aparición y disciplina del hombre (espiritual) en el mundo sensible, rumbo al Pléroma. La historia de los demás tipos humanos, animal y terreno, se subordina a la del hombre espiritual [...] Así ideada la antropología, fácilmente se orienta -entre los gnósticos- hacia la "teología"” (62).

Aún más. Ya he insinuado que Jonas también se refiere a la divinidad que surge con la Kehre, proponiendo como término de la comparación a ese último Dios enteramente inconmensurable con el de la historia de las religiones. Dado que en todo caso Jonas entiende que luego del giro la analítica existencial de Ser y tiempo no es desdeñada sino que sigue operando en el pensamiento de Heidegger (eso sí, sometiéndose la existencia o Dasein, radicalizado y considerado ahora como $D a$ sein, al acontecimiento de la verdad originaria del ser), creo que es legítimo decir que aquella figura divina, siempre acusada de paganismo, bien pudiera merecer al mismo tiempo el calificativo de gnóstica, aun cuando no sea más que en el sentido tradicional de aquellos sistemas que se distinguirían con cierta nitidez del de los grandes heresiólogos eclesiásticos que los combatieron como perversión herética y -en cuanto tal- paganizante del cristianismo. La de Jonas sería entonces una aproximación a Heidegger que lo compara no solamente con algunos elementos antropológicos y cosmológicos del gnosticismo, sino también con su teología soteriológica. La operación supone la legitimidad y necesidad de comparar, en una cierta aproximación, la reflexión tardía de Heidegger con el sistema religioso-filosófico de los gnósticos. Para ello puede argüirse en general que los fenómenos no se nos abren más que a través de aproximaciones intrínsecamente diversas. No por ser válidas y efectivas aproximaciones a la gravitación la de la teoría de la relatividad y la de la mecánica cuántica, deja de ser también válida y efectiva en su nivel la aproximación newtoniana a la misma, incluso aunque esta y aquellas no puedan ser ambas estrictamente verdaderas por ser lógicamente contradictorias, incompatibles (63). Mutatis mutandis, lo que ha de juzgarse en este caso es si la aproximación de Jonas, aun conteniendo yerros, es de todas formas fundamentalmente justa y fructífera para interpretar al Dios de Heidegger (e incluso de vuelta, a los propios dioses gnósti$\cos )$. A mí me parece que, incluso desde esta perspectiva según la cual la pluralidad de aproximaciones es admisible y aconsejable, el rendimiento de la aproximación de Jonas es más bien pobre, de poca monta, ya que aquella divinidad última casi en nada recuerda al buen Dios abismático y transmundanal y al Demiurgo creador malo o inepto de los gnósticos. Cuestionable no es la justificación de la pluralidad de posibles aproximaciones a un fenómeno como el gnosticismo, por supuesto, sino el

(62) Orbe, Antonio, Introducción a la teología de los siglos II y III (Madrid, Sígueme 1988), pp. 4-5 y 1052-1053.

(63) Vid. Popper, Karl, "Sobre el conocimiento y la ignorancia", en En busca de un mundo mejor (trad. J. Vigil, Barcelona et alii, Paidós 1994), p. 61, y Valdivieso, Jaime, Ciencia y poesía. Conversaciones con Claudio Teitelboim (Stgo. de Chile, LOM 1996), pp. 31-32 y 35-36. 
hecho más puntual de que el tipo de aproximación que cultiva Jonas es enormemente genérico y por ende que su pretensión de validez, eficacia y verdad no puede ser sino vaga y ambigua. Para asegurar la fundamental semejanza del nihilismo dualista del gnosticismo con el del existencialismo, así como la proximidad y coincidencia de la teología soteriológica de ambos, Jonas tiene que excogitar forzadamente una óptica interpretativa amplísima. Resulta ostensible, empero, que con idéntica óptica general pudiera establecerse a la vez y con parecida energía la semejanza del pensar de Heidegger con otras teorías dualistas que en verdad se encuentran casi en sus antípodas, como la platónica o incluso la cartesiana. Y es que a un nivel muy lejano o comprehensivo de aproximación, aun las más disímiles construcciones filosóficas y culturales empiezan a parecerse o encontrarse, cuando no a solaparse. Por eso el procedimiento comparatista de Jonas tiene que afrontar la dificultad prácticamente insalvable de no precisar más que muy lata y confusamente el carácter que Heidegger y los gnósticos atribuyen a la divinidad y a las marcas existenciales de la conditio humana. Si las reflexiones heideggerianas son calificables como gnósticas, casi con igual razón podrían ser tratadas como neoplatónicas o racionalistas, como idealistas o cercanas a alguna filosofía del espíritu. Decía Hegel, more germanico, que en la noche del Absoluto "todas las vacas son negras (alle Kühe sind schwarz)" (64). Por lo mismo, al ser un fenómeno histórico de la antigüedad tardía en el que confluye la síntesis greco-latina y la influencia emergente de las culturas del oriente próximo, uno que en todo caso posee oscuras raíces y muy peculiares características religiosas y especulativas, el gnosticismo tolera mejor la comparación con otras constelaciones de ideas de su época (65) que con filosofías y teologías modernas o contemporáneas (66). De ahí también proviene la dificultad de adjetivar gnósticamente a la modernidad o a ciertas teorías y políticas de los últimos siglos (67). El caso del idealismo alemán es ejemplar. Recordándolo, uno podría decir no solamente que la de Jonas es una aproximación demasiado vaga y poco productiva, sino sospechar que sus investigaciones, yendo de Heidegger al gnosticismo y volviendo

(64) Phänomenologie des Geistes, en Hegel, G. W. F., Hauptwerke in sechs Bänden Vol. 2 (Hamburg, Felix Meiner 1999), p. 17.

(65) Como el estoicismo, la doctrina de Orígenes, la filosofía de Plotino y Proclo, la religión de Manes y la teología de los Capadocios y de san Agustín; cf. Trías, Eugenio, La edad del espíritu (Barcelona, Debolsillo 2006), pp. 191-231, esp. 193-200, donde se inserta esta precisa comparación en una sugerente pero altamente especulativa filosofía de la historia.

(66) Cf. por ej. Aland, Barbara, "Die Wirkung der Gnosis in der neueren theologischen Literatur", en Koslowski (n. 46), pp. 165-184.

(67) Es lo que, sin restringirse siquiera a los tiempos modernos, postula paradigmáticamente Eric Voegelin en La nueva ciencia de la política. Una introducción (trad. J. Ibarburu, Buenos Aires, Katz Editores 2006), pp. 133-194. Véase al respecto, primero, la crítica de Hans Kelsen en ¿Una nueva ciencia política? Réplica a Eric Voegelin (trad. I. Rodríguez, Buenos Aires, Katz Editores 2006), pp. 168-244, que ve en tales postulados una muy irregular concepción del gnosticismo, por aplicarse no solo a las religiones filosóficas de los primeros siglos de esta era sino también a posturas tan diversas y alejadas entre sí como las de Joaquín de Fiore, Calvino, el puritanismo, Hobbes, el enciclopedismo, Comte y Marx, el leninismo-estalinista y el nacionalsocialismo, entre muchas otras. Véase también, luego, la tesis de Hans Blumenberg en Die Legitimität der Neuzeit (Frankfurt a. M., Suhrkamp 1996), pp. 137-149, según la cual la modernidad es precisamente, por su tendencia secularizadora o mundanizante, la radical superación (Überwindung) del gnosticismo, por más que en ella -aunque fuera de su línea propia, incluso contra esta- sigan dándose resurgimientos gnósticos. 
de este a aquel, en vez de introducirse de manera virtuosa en el círculo hermenéutico, están rigurosamente viciadas de anacronismo y de -sit venia verbo- 'proyeccionismo'. Jonas tal vez encuentre en el gnosticismo y en Heidegger lo que ya ha puesto en cada uno precisamente a partir del otro, del mismo modo que en el siglo XIX Baur (en Die christliche Gnosis) procedió anacrónica y proyectivamente cuando creyó ver una analogía o parentesco entre el gnosticismo y el hegelianismo donde había más bien una retroyección del sistema en el mito y una proyección de este en aquel (68).

Con todo, si se critica a Jonas por su inclinación a independizar la cosmología y la antropología gnóstica de su esencial marco teológico-salvífico y a cometer craso anacronismo y ostensible proyección al analogar el pensar de Heidegger con la religión filosófica de los gnósticos, también puede ser salvada su decisión de aproximarse a ese pensar desde una generalísima perspectiva. Nada impide en principio adoptar puntos de vista amplios y gruesos, siempre claro que el resultado de tal distanciamiento interpretativo se justifique por sus frutos. Por ello parece posible avanzar más allá de las tesis de Jonas. Estas quizá (solo quizá) podrían servir de mejor manera para iluminar algunos caracteres de las alusiones a Dios que hace Wittgenstein en el Tractatus (69). Pero respecto de Heidegger, si se defiende la legitimidad de adoptar perspectivas genéricas, sería mucho más certero y productivo comparar las nociones de Dios, mundo y ser humano de Heidegger con las que polémicamente enfrentaron a eclesiásticos y sectarios. Tal polémica ofrecería un fresco filosófico y religioso más apto que el de las solas posturas gnósticas para caracterizar algunos de los rasgos de la teología soteriológica, la antropología y la cosmología extraíbles del peculiar pensamiento heideggeriano. Así se concede que las tentativas de Heidegger, sin ser enteramente interpretables a la luz de antiguas disputas filosófico-religiosas, sí pueden encuadrarse gracias a ellas, y que mejor que un contraste con las solas doctrinas gnósticas es una doble comparación: por un lado, con las ideas de barbelognósticos, ofitas, naasenos, peratas, setianos o cainitas, de Satornilo, Basílides, Valentín, Ptolomeo o Hermógenes, y por el otro, con las de Justino, Ireneo, Hipólito, Clemente, Orígenes, Tertuliano o Epifanio. Heidegger podría ser un libre repetidor, en un sentido nada estricto y solo lejanamente aproximado, de las posturas que entonces se enfrentaron:

“a primera vista, solo los gnósticos hacen teología con su 'anthropos', y anuncian desde los preliminares del mundo - con el Pléroma- el destino de lo

(68) Cf. Jaeschke, Walter, "Der Gnostizismus und die spekulative Philosophie des deutschen Idealismus”, en Koslowski (n. 46), pp. 91-105, esp. 93-97. Lo que no obsta a que sigan existiendo ensayos que, en sentido contrario, pretenden analogar al idealismo con las mitologías gnósticas; cf. por ej. Rezvykh, Petr, "Probleme des Gnostizismus in der Philosophie der Offenbarung F. W. J. Schellings", y Koslowski, Peter, "Philosophische Religion als Form postmodernen Denkens", también en Koslowski (n. 46), pp. 107-123 y 223-238 (esp. 227-236), respectivamente.

(69) "Cómo sea el mundo, es para lo más alto perfectamente indiferente. Dios no se revela en el mundo (Wie die Welt ist, ist für das Höhere vollkommen gleichgültig. Gott offenbart sich nicht in der Welt)": Tractatus logico-philosophicus, en Wittgenstein, Ludwig, Werkausgabe Vol. 1 (Frankfurt a. M. 1984), $\mathrm{N}^{\circ} 6.432$ (p. 84). El mayor aire gnóstico de Wittgenstein por comparación con Heidegger es algo que sugiere, por ej., Brague (n. 40), pp. 313-314. 
espiritual a Dios. Solo Ireneo hace antropología con su 'theós', y anuncia desde los preliminares del mundo sensible el trabajo del Espíritu en el hombre para levantarle de carne a espíritu, de plasma a Hijo de Dios. Semejante perspectiva arroja luz bastante sobre las etapas de la Economía. Gobernadas, entre unos, por la preocupación de redimir lo divino; entre otros, por la de salvar el alma; y en otros, por la de deificar la Carne" (70).

Es cierto que la amplificación del término con el que se mensura a Heidegger ensancha nuevamente la perspectiva. La ganancia, empero, es mayor que la pérdida. Por una parte, la nueva aproximación determina más ceñidamente la noción de mundo sostenida por Heidegger, que si tiene por momentos el significado peyorativo de lugar de la caída habitual, de la impropiedad y de una desazonante inhospitalidad, también tiene el sentido de supra o anteproyecto existencial, último horizonte de sentido de todas las remisiones significativas, y más aún, de despliegue y apertura del ser, de cuaterna conformada por tierra, cielo, mortales y divinos. Pese a todo lo que lo amenaza, el mundo es teatro del paso señalizante de Dios y, en consecuencia, sitio de salvación que en cuanto tal puede y tiene que ser habitado, cultivado y protegido. Es algo que entronca con la óptica de los eclesiásticos que, lejos de desdeñar, valoran cristológicamente la materialidad del cosmos y la carnalidad de la vida humana. Por idéntico motivo la nueva aproximación es también propicia para aludir a la imagen del ser humano sostenida por Heidegger, que no se caracteriza solamente por el énfasis en su tendencia cadente y anónima o por la práctica ausencia de análisis de su dimensión corporal, sino también por el resalte de su apertura o novedad, en cuanto el fundamento del ser humano es 'estar-ahí' (Da-sein), ser el ahí mismo del ser que acontece. Aún más: Heidegger difícilmente aceptaría el odio contra la carne o el anticosmismo gnóstico. El hombre no es para él una chispa divina inmortal angustiosamente encarcelada en la materia; es más bien una existencia que ha de encarar su propia carne finita y la angustiante posibilidad par excellence que es su muerte. Pero sobre todo, la nueva aproximación caracteriza mejor los rasgos ambivalentes del último Dios heideggeriano, que si en ocasiones se asemeja al Dios desconocido, inobjetivable y abismático al que ascienden y se reintegran por iluminación los espirituales, otras veces se acerca a la Gracia salvadora como acontecimiento vertical, descenso inmerecido, imprevisible e indisponible del Altísimo, mas de todos modos real, histórico, finito y encarnado. A ese Dios que salva, parece conceder Heidegger, el ser humano tiene que responder no tanto con un conocimiento iluminador que lo eleva y reintegra a la Luz suprema, sino ante todo mediante el acto de la fe, la entrega confiada de todo su ser que así acoge la kénosis del misterio sagrado, ya que la existencia no tiene en sí misma las fuerzas necesarias para liberarse de su pecado ni, tampoco, para procurar el enderezamiento de la época actual gobernada por la mentalidad técnica. Es verdad que el creyente en el que piensa Heidegger es el conjunto elitista de los escasos que plantean y sostienen la inquisición esencial del ser, pero también es cierto que él parece ver con simpatía la fe fiducial ofrecida universalmente a toda la humanidad del cristianismo 
originario -el que de veras vale a sus ojos-, esa fe que es decisión radical, confianza sin condiciones, entrega plena y no de la pura inteligencia, y que, además de pertenecer al cristianismo desde sus más tempranos momentos, fue también señalada por los eclesiásticos originales.

En fin. Ya dije al comenzar que la relación de Heidegger con el cristianismo fue constitutivamente ambigua. Ahora quizá se pueda caracterizar mejor esta ambigüedad diciéndose que en la mente de Heidegger cabe entrever algo -un levísimo resplandor- de la antigua gigantomaquia de la que participaron los gnósticos y sus contradictores, una suerte de titubeo, de oscuro y tal vez poco consciente ir y venir por los meandros sutiles de esa sensacional controversia entre un cristianismo deliberadamente carnal y otro que, justo en la medida en que rechaza la carne, tiende inevitablemente al paganismo. Desde esta muy ensanchada perspectiva, entonces, Heidegger no debiera ser emparentado exclusivamente con un gnóstico fuera de tiempo, como el nórdico protagonista del cuento de Borges:

“en el Asia Menor o en Alejandría, en el segundo siglo de nuestra fe, cuando Basílides publicaba que el cosmos era una temeraria o malvada improvisación de ángeles deficientes, Nils Runeberg hubiera dirigido, con singular pasión intelectual, uno de los conventículos gnósticos. Dante le hubiera destinado, tal vez, un sepulcro de fuego; su nombre aumentaría los catálogos de heresiarcas menores, entre Satornilo y Carpócrates; algún fragmento de sus prédicas, exornado de injurias, perduraría en el apócrifo Liber adversus omnes haereses o habría perecido cuando el incendio de una biblioteca monástica devoró el último ejemplar del Syntagma. En cambio, Dios le deparó el siglo XX y la ciudad universitaria de Lund" (71).

Más bien, la irresuelta ambigüedad de Heidegger para con el cristianismo pediría ser entendida como un lejano e impreciso eco de esa magnífica lucha intelectual y espiritual de la que Orbe tanto gozaba:

“gusta asistir a la creación de la dogmática. Los amigos de la libertad doctrinal pueden presenciar en la segunda mitad del siglo II el duelo de dos titanes: la gnosis libérrima, intelectual, que presume de atemperarse al helenismo, a beneficio mutuo, de la fe cristiana y de la filosofía; y la tradición pública apostólica de la Iglesia, que sacrifica individuales tendencias al depósito de la $\mathrm{Fe}$, y se mueve con admirable soltura en el campo inmenso de la Revelación. Tiene su encanto sentir la pujanza de la teología 'in fieri', descubrir variantes, temas espontáneos aún no prejuzgados, en vías de desarrollo, y poderlos caracterizar con su peso específico, antes que degeneren en esquemas o en tradiciones sin vida. Si place seguir la trayectoria divergente de la dogmática a partir de unos mismos testimonios de Escritura, gusta aún más sopesar los principios en que comulgaban tirios y troyanos" (72).

(71) Borges, Jorge Luis, “Tres versiones de Judas”, en Obras completas Vol. 1 (Buenos Aires, Emecé Editores 1989), p. 514.

(72) Orbe (n. 62), pp. 6-7. 
En honor de la justeza, en todo caso, debiera añadirse que si esta nueva comparación es más certera que la que propone Jonas, de todos modos sigue siendo gruesa, pues en Heidegger no solo conviven ambiguamente rasgos del gnosticismo cristiano con otros del cristianismo eclesiástico, sino que en ocasiones también despunta alguna admiración por la teología luterana de la cruz y de la fe, cierta propensión inocultable por la mística y la teología negativa, sin descartar tampoco del todo el influjo de Hölderlin y su pagana valoración de la religión de las divinidades griegas e incluso la apertura de una meditación de aires al menos parcialmente orientales sobre el no fundamento, el abismo, el vacío uno y único de todas las cosas.

\title{
RESUMEN
}

Este trabajo pregunta por el sentido del complejo y peculiar recurso heideggeriano a la divinidad. Deteniéndose particularmente en la interpretación de Jonas, argumenta que el gnosticismo es solo muy aproximadamente afín al pensamiento de Heidegger. Y sugiere que podría encontrarse una mejor analogía para este pensamiento en la polémica que enfrentó al cristianismo gnóstico con el eclesiástico, aunque esto también sea una gruesa aproximación que deja abiertas otras posibilidades interpretativas.

Palabras clave: Heidegger, Jonas, Dios, gnosticismo, cristianismo, filosofía de la religión, antropología, teología, soteriología.

\begin{abstract}
This paper deals with the sense of the complex and peculiar Heideggerian resource to divinity. Analyzing particularly, the interpretation of Jonas, it argues that the Gnosticism is only very approximately compatible to the thought of Heidegger. And it suggests that could be found a better analogy for this thought, in the controversy that faced the Gnostic Christianity with the Ecclesiastic, although this is also a thick approximation that leaves other interpretative possibilities open.
\end{abstract}

Key words: Heidegger, Jonas, God, Gnosticism, Christianity, philosophy of religion, anthropology, theology, soteriology. 